\title{
John Gardner and the morality of choice ${ }^{1}$
}

\author{
James C. Schaap \\ Department of English \\ Dordt College \\ IOWA \\ USA
}

\begin{abstract}
John Gardner and the morality of choice

Although interest in literary theory has prompted much discussion concerning the relationship between literature and religious worldview, that discussion has taken place primarily among theorists and not practitioners. Christian writers have few contemporary models by which to note integration of what one confesses and what one creates. John Gardner, whose On moral fiction created a firestorm a decade ago in North America, offers a view of fiction which places significant emphasis on a fundamental assertion about the nature of humanity, specifically that men and women are choicemakers. The framework for this view of the human condition and his view of the role of story in our lives, as well as the life of the writer, is of substantial help in visualizing what we are about as Christian fiction writers.
\end{abstract}

\section{Introduction}

I cannot begin to count the hours I have spent writing in the last 18 years. I have started several novels, completed three; written full-length plays, several books of devotional readings, a book of journalistic portraits, three books of short fiction, maybe 75 short stories and a couple dozen essays. I have begun a score of other things that never made it. But after all that work, I find myself no closer to grasping a full intellectual understanding of what it means to be a Christian writer than I was 18 years ago, when I started a novel as a means of teaching myself to write.

1 Reworked version of a paper delivered at the Intemational Conference on "Christianity and literature at the turn of the twentieth century", held at Potchefstroom, August 1995. 
I believe in God. I worship him, and I write. Just exactly how my faith and my work are related still remains a mystery. My own fiction illustrates my own confusion, I suppose. A few years ago a New York agent said this about my work:

I feel the strong, religious tenor of the work would make the collection more salable to a [religious publisher]. The problem with religious publishers is that they find it difficult to publish any work that might offend any [emphasis his] of their readers, and it's nearly impossible to tell the truth without offending someone in the congregation.

I understand the difference between aesthetic questions, and sociological or ecclesiastical questions. I know that the use of profanity and vulgarity, or depicting sexuality in a work of fiction may offend readers with whom I regularly worship. But I believe that problem is not so much an aesthetic problem as it is a sociological, ecclesiastical, or, if you will, even a family problem.

Such problems are worthy of exploration, but what I wish to address are the questions that pertain to the work of writing fiction, not those which arise from our reaction to it. The question that plagues me is this: what is the shape of fiction which glorifies God? What should such fiction look like?

Years ago already, I stumbled on the work of the late John Gardner, a fiction writer and academic, whose principal work created significant controversy in the North American literary world more than a decade ago. What understanding I have of what it means to be a Christian writer is based largely on John Gardner's ideas. His work is central to what 1 see as the task of a Christian writer; furthermore, among writers at least, it remains at the centre of any North American discussion of "morality" in fiction, or the purpose of literature, when in this post-modemist academic climate such questions are even raised.

\section{2. "a stranger comes to town" / "a man goes on a trip"}

I met John Gardner at the 1980 Bread Loaf Writers' Conference, where he was one of the featured writers, and where he explained the two basic plot forms into which he felt most novels and short stories could be divided. In the first form, one he characterized as "a stranger comes to town", the action of the story is initiated by an outsider. In such stories, the protagonist and reader stand as spectators before the driving force of the story - the stranger, that force about which we know significantly less.

The second form, one he characterized as "a man goes on a trip", works in an opposite fashion: the main character's quest initiates the action. In this story, 
readers know the nature of the protagonist's desire or goals, and the story's suspense results from the pursuit of those goals.

Most stories, Gardner claimed, fit into one of those two forms. But the second, he argued, was the superior form since only in that type of story is the reader able to empathize with the character and his or her quest.

What I would like to do is to present Gardner's view of the function of literature as a model, and in the process define more fully the nature of the difference he drew between those two plot forms by showing that the basis for his claims goes to the very roots of his view of fiction, a view he has set down most clearly in his very controversial On Moral Fiction (1978), and in two later volumes on the craft of fiction, On Becoming a Novelist (1983) and The Art of Fiction (1984). In explaining Gardner's view, I intend also to lay out a view of writing which I believe to be as close to a "Christian" view of fiction as any I have ever encountered.

\section{Gardner's view of literature}

It is important that we see Gardner's distinctions as emanating from character and not plot, however. These two story-types are less "story-types" than they are "character-types." According to Gardner, character, "the very life of fiction", is the animating force in any story, especially when the protagonist has an identifiable motivation for action, when he is "a man going on a trip". "I think in a good book or movie," he says in an interview, "you present people struggling heroically for what they value, and the reader's natural response to a well-written story about someone heroically struggling for what he believes to be good ends, the reader sympathizes with that character and wants to be like that character ..." (Mendez-Egle, 1983:102).

Suspense, he claims, is created when that heroic struggle encounters obstacles; suspense originates in what he calls elsewhere the protagonist's "driving force": "Suspense, rightly understood, is a serious business: one presents the moral problem - the character's admirable or unadmirable intent and the pressures of a situation working for and against him" (On Moral Fiction:114). The key word here is intent; Gardner wants his readers to see that protagonists must have purpose or drive - that is, they must be characters going on a journey, not those who passively receive action created by someone or something else.

The kind of suspense I am interested in is that which arises when the reader is given all the information, good solid information. He knows what the character's problem is and what his goal is and what the opposition is and the suspense is, what will he do, what will happen to him if he does that, what will she say, etc. (Mendez-Egle, 1983:98). 
In On moral fiction he explains how he wrote his novel October Light, and in the process shows us the same kind of cause or force animating his own protagonist. Clearly, the character he describes fits the "a man going on a trip" pattern:

One begins a work of fiction with certain clear opinions - for instance, I myself in a recent novel, October Light, began with the opinion that traditional New England values are the values we should live by: good workmanship, independence, unswerving honesty, and so on - and one tests those opinions in lifelike situations, puts them under every kind of pressure one can think of, dlways being fair to the other side ... (Gardner, 1978:114).

If we rephrase the Bread Loaf distinctions, we may see the lines he has drawn more clearly. He is talking in the first instance ("a stranger comes to town") about characters (the town itself) who are acted upon, recipients of the action of the novel. On the other hand, when he speaks of the second type ("a man goes on a trip"), he is describing characters who have purpose or "driving motive". Good fiction - that is, fiction people enjoy - features characters who act, not characters who are simply acted upon.

But what makes active characters superior to passive characters? The answer lies in a value judgment which Gardner makes in On Moral Fiction.

\subsection{Moral fiction}

What Gardner meant by "moral fiction", has little to do with happy endings or the triumph of good over evil. Gardner begins the second chapter of that book by warning against such misplaced notions: "By 'moral' I do not mean some such timid evasion as "Not too blatantly immoral."' Furthermore, he does not mean "that art should hold up cheap or cornball models of behavior": "I do not mean, either, that what the world needs is didactic art. Didacticism and true art are immiscible; and in any case, nothing guarantees that didacticism will be moral" (Gardner, 1978:18-19).

What Gardner does mean with the use of the word moral has more to do with the means by which art is created as the ends it accomplishes. "The morality of art is, as I've said, far less a matter of doctrine than of process," he says later in the book. "Art is the means by which an artist comes to see: it is his peculiar, highly sophisticated and extremely demanding technique of discovery" (Gardner, 1978:91). Artists, he says, rely on imagination as a test of truth. When the writer works, all the information and experience she has is filtered through the imagination to create, in an evolutionary manner, the life of the character. Throughout the process of writing a novel, the writer asks questions and makes judgments based on his discoveries, and the result is a process by 
which both writer and reader make order out of chaos. At work, the writer's imagination links him with the imagination of the reader, a theory is rooted in the Romantic belief that the artist's imagination touches some line of shared intuition in all of us. When the artist's vision fails to reach that deep base of what Faulkner called "the eternal verities", then the survival of his work cannot be assured, even though he may attain critical success.

Gardner (1978:16) makes a claim for this notion of the understanding reached by the reader in "moral fiction", when he says that "fiction is thus a convincing and honest but unverifiable science (in the old sense, knowledge)". It is unverifiable because "it depends on the reader's sensitivity and clear sense of how things are, a sense for which we have no tests".

A protagonist with an idea worth advocating or a cause worth following, even if that cause has meaning only for himself, encounters a series of obstacles which likely force him to adjust his values or change; that process will bring him to a more comprehensive understanding of himself and his predicament. This pattern - a series of adjustments, forward then backward then forward again is the same pattern by which writers create fiction, Gardner says. Thus, fiction is a unique means by which both writer and reader come to understand themselves and their values. When the protagonist's quest, through the writer's creative process, strikes a resonant chord with the reader's imaginative sense, the fiction is "moral": "True art is by its nature moral. We recognize true art by its careful, thoroughly honest search for and analysis of values" (Gardner, 1978:19).

The result of such "morality" in the process of writing is fiction which is lifegiving, both in the means by which character is created and in the effects it creates in the readers. "I have claimed," Gardner says, "that art is essentially and primarily moral - that is life-giving - moral in its process of creation and moral in what it says" (Gardner, 1978:15). A few pages later, he returns to the idea: "No one seriously doubts, surely, that Tolstoy's essential argument is right: ideals expressed in art can effect [sic] behavior in the world, at least in some of the people some of the time" (Gardner, 1978:27).

Yet, art's potential for positive effect on public morality is not predicated on what it "teaches" us, but instead on the "morality" of its creation. "I agree with Tolstoy," he says, "that the highest purpose of art is to make people good by choice" (Gardner, 1978:106). Here again, the emphasis is upon "choice". In the same way that the writer exercises options for the characters and creates plots through the reliability of her own imagination, the reader feels the possibilities of those choices, and that effect, he says, is "life-giving" and "moral", art's moral gift to man. 
"Moral fiction", then, is that which allows readers to make choices about the values in their lives. "True art," he claims, "by specific technical means now commonly forgotten, clarifies life, establishes models of human action, casts nets toward the future, carefully judges our right and wrong directions, celebrates and mourns" (Gardner, 1978:100).

Perhaps the clearest example of what Gardner assumes to be "moral fiction" occurs in On Becoming a Novelist (1983), in a section in which Gardner creates a plot and characters to aid young writers in understanding what happens in the process of writing. The imagined characters, named Frank and Wanda, are a father and a daughter who, unaware of their familial relationship, happen to live as neighbours. Gardner creates a situation in which Wanda begins to feel sexual attraction for Frank. He then goes on to describe the possibilities for the characters and the story:

If Frank is clearly drawn and interesting, a lifelike human being, the reader worries about him, understands him, cares about the choices he makes. Thus if Frank at some point, out of cowardice and indecisiveness, makes a choice any decent human being would recognize as wrong, the reader will feel vicarious embarrassment and shame, as he would feel if some loved one, or the reader himself, were to make such a choice. If Frank sooner or later acts bravely, or at least honestly, selflessly, the reader will feel a thrill of pride as if he himself or some loved one had behaved well - a pride that ultimately expresses pleasure in what is best not just in the made-up character but in all humankind. If Frank finally behaves well, and Wanda show unexpected (but not arbitrary or writer-manipulated) nobility, the reader will feel even better. This is the morality of fiction. The morality of the story of Frank and Wanda does not reside in their choosing not to commit incest or in their deciding they will commit incest. Good fiction does not deal in codes of conduct - at least not directly; it affirms responsible humanness (Gardner, 1983:49-50).

\subsection{Responsible humanness}

What he argues for, then, is "responsible humanness", and what that phrase seems to mean is that characters be endowed with the opportunity of real choice in their lives. Characters who have choices about themselves and their relationship to the world are the ones, he would say, who are most human. When we understand this belef, we can see why Gardner regards characters who have no choices (as in "a stranger comes to town") as less human than those characters whose attitudes or goals give them something to carry into the press of life. Characters who lack free will are passive characters, victims of powers greater than themselves. Thus, they are characters who lack the morality of choice. To Gardner, such characters not only carry less potential 
for our sympathies as readers; they are simply less human, since true humanness means having the opportunity to make choices.

If Gardner is correct, one cannot help but ask why so many writers insist on creating characters who lack the humanness of choice? Or, if we use the Bread Loaf distinctions, why aren't more writers creating the "man goes on a trip" characters?

The answer lies at least partially in Gardner's assessment of the temper of our times. He points out that characters who lack free will are simply in vogue today. "We have seen since World War II," he says in On Becoming a Novelist, "all over the world, a rise of nonprofluence (actions leading nowhere, as in the plays of Samuel Beckett) and unended fiction (as in John Fowles' The French Lieutenant's Woman)" (Gardner, 1983:84).

But why are such styles popular? Gardner says we have reached a period characterized by intense groping for new forms and modes of art. This search is occurring and is observable in many fields, by such related phenomena as a de-emphasis on melody in modern music, on plot in the modern novel, and on identifiable image in photography (Gardner, 1983:10). Art's continuous search for new insight necessitates innovation in form. Today, he says, fiction writers, like musicians or sculptors, are abandoning old forms in hopes of discovering new opportunities elsewhere.

He argues that such searches do little more than uncover some things left abandoned in the past, however. His call for "moral fiction," he would say (like his assertion that "good" literature has characters who act and make choices), is an attempt to refurbish an old verity - "art is as original and important as it is precisely because it does not start out with clear knowledge of what it means to say" (Gardner, 1983:13). It proceeds instead, powered by the imagination, by the writer's making choices in the very flow of the process of composition, choices which become embodied in character and thereby serve to affirm life itself by verifying that all human beings can and do make such choices.

One of the reasons Gardner's idea of "moral fiction" incited such controversy when his book appeared is, quite likely, that affirming his ideas about character in fiction necessitates a belief in man's free will - a leap of faith which some writers and editors may be reluctant to take. Why? Again, because doubt is, he claims, part of the marrow of our culture. The effect of doubt is crippling, he says, since it renders us unable to make any judgments and leaves us in a moral vacuum: "If we are unable to distinguish between true morality - lifeaffirming, just, and compassionate behavior - and statistics (the all but hopeless situation of most of humanity) or worse, trivial moral fashion, we begin to doubt morality itself" (Gardner, 1983). Such confusion results, he says, in 
John Gardner and the morality of choice

Normal Mailer's hailing Charles Manson as "intellectually courageous, ... for the brave pursuit of truth changes utterly when truth becomes whim. The man so infected may begin to feel guilty chiefly for possessing a moral code at all. Confusion and doubt become the primary civilized emotions" (Moral Fiction:76).

It seems clear from such critiques that Gardner has a specific ontology of his own. Yet, he is less clear about his gods than he is about the necessity of belief. Like William James, Gardner seems unsure of the reality of free will, but he is clearly convinced that not believing in its reality is less useful than believing. In On Moral Fiction, Gardner appears to cling stubbomly to the necessity of belief - if in nothing else, in the power of art:

The art which tends towards destruction, the art of the nihilists [and] cynics, ... is not properly art at all. Art is essentially serious and beneficial, a game played against chaos and death, against entropy. It is a tragic game, for those who have the wit to take it seriously, because our side must lose; a comic game - or so a troll might say - because only a clown with sawdust brains would take our side and eagerly join in (Gardner, 1978:6).

According to Gardner, the practical necessity of belief itself warrants our faith. If Gardner appears to believe that anything be true, it would seem to be that, simply, humanity must believe or else die.

One more substantive reason exists for Gardner's distaste for characters who lack free will - and "the stranger comes to town" formula. In an early discussion in The Art of Fiction (1984), Gardner argues that those who are serious about writing need to be very serious about education. Education, he claims, functions in such a way as to teach us the other side of our own arguments, thereby helping us realize the dignity and worth of those we might consider enemies.

He then goes on to use Steinbeck's The Grapes of Wrath as an example of a book which has a potential it never reaches. Gardner claims Steinbeck knew all there was to know about the Oklahoma farmers and their new lives in California, but

... he knew nothing at all of the California ranchers who employed and exploted them; he had no clue to, or interest in, their reasons for behaving as they did, and the result is that Steinbeck wrote not a great and firm novel but a disappointing melodrama in which complex good is pitted against unmitigated, unbelievable evil (Gardner, 1984:10).

Gardner claims Steinbeck did not care about the characters on the other side of the argument, did not understand the story that the ranchers would have told, 
because he did not want to hear it. He knew the Okies, and he understood them; but he never knew the ranchers. Gardner implies that to Steinbeck the actual ranchers were stock figures of evil. Because he failed to see them as human beings, the ranchers in the novel are not human, making the novel less a work of art.

Gardner's point is that any writer's ability to create human characters is dependent upon the degree of concern and care which he or she has for them. In On becoming a novelist, he explains what he sees as the psychological requirements for being a writer:

To be psychologically suited for membership in what I have called the highest class of novelists, the writer must be not only capable of understanding people different from himself but fascinated by such people. He must have sufficient self-esteem that he is not threatened by difference, and sufficient warmth and sympathy, and a sufficient concern with faimess, that he wants to value people different from himself, and finally, he must have, 1 think, sufficient faith in the goodness of life that he can not only tolerate but celebrate a world of differences, conflicts, and oppositions (Gardner, 1983:32).

Few writers have ever embodied that kind of care as fully as Chaucer, according to Gardner. "I think a good artist has to be fair in all his characters. He has to be a generous human being, and Chaucer of course is the absolute model of it" (Mendez-Egle, 1983:104).

Gardner's Bread Loaf plot distinctions, thus, follow clearly from his basic assertions about the way which fiction, and art itself, operate. According to him, characters can be truly human only when they have goals ("a man goes on a trip"), when they act through choice. The source of that choice-making is inherent in the writing process, a process through which the writer's own imagination discovers options and chances and thereby endows the characters with will. When characters have the morality of choice-making, Gardner claims, they have the humanness which readers want to discover in fiction.

On the other hand, if the writing process itself does not allow for discovery on the part of the writer, his or her characters will lack the morality of choice and readers will not find themselves drawn to those characters. "Insofar as we're unable to care about the characters," he says in On Moral Fiction, "we can work up no interest in the issues; or if we do care about the ideas, it is only because we accept the writer's value judgments" (73). 
John Gardner and the morality of choice

\subsection{The morality of choice}

For Gardner, it is the morality of choice, implicit in the process of writing and thereby manifest in the lives of fictional characters, which makes stories both good and lasting. "A man goes on a trip" is a formula for a character which is naturally superior to "a stranger comes to town," because a character with a goal is, according to Gardner, the character whose humanity can and will be verified in the creative process undertaken by the writer, and, as a result, by the reader as well.

Those of you who know anything at all about literary theory will recognize that there is nothing at all new in Gardner's ideas about the place and task of imaginative writing; they belong to Aristotle and Sydney, and they likely belonged to just about everybody up until the Modern Age. Whatever their origins, I find his distinctions helpful in describing the writer's task, his or her obligation to choice, and thereby, to hope, in today's world. Furthermore, I find that his commitment to accuracy, to felt life, to be the most important characteristic of literature itself. I find him an inspiration in the process of my own work.

I sometimes wonder if there really is such a thing as the "Christian perspective": perhaps it can only be some vague and nebulous inspiration. Perhaps all the Lord requires of us is that, in whatever our fields, we continue to ask the question - how does my work stand as a revelation of my faith in the Almighty? Although there may be no single answer, that fact does not absolve us of continuing to ask the question.

For the time being, I like Gardner. And what has he taught me? Simply, this. That morality in fiction does not reside in the prescription of a certain way of living or the prohibition of certain words and scenes. It resides primarily in accuracy, the "felt life" of characters whose existence appears on the page, created there, as if by magic, by the process of writing itself, characters fully human. Christian writers cannot settle for characters whose attributes, dialogue, reactions to events appear any more or less than human.

And what do we mean by human? Simply, characters endowed, as all of us are, with the capability of choice. Moral fiction, by Gardner's definition, is fiction which is true to what we know to be human - true specifically, he says, to our capacity for decision-making. We all make choices, and therein, Gardner argues, lies our essential humanness. When stories are true to that humanness, they are truly moral stories. 
James C. Schaap

\section{One Christian's response}

Let me try to make one adjustment to the Gardner thesis, an adjustment which grows, I believe, from my own commitment to truth as it bases itself in a Christian world view. The summary of God's law draws us to our responsibilities as believers: to love God above all, and our neighbours as ourselves. Love for neighbour, in my mind, necessitates a writer's creating characters true to our view of man as both a fallen creature, subject to taking wrong paths when options present themselves, yet capable at the same time of great heroism, stamped eternally, as we are, with the image of God. To be human is to carry both darkness and light. Writing which is moral, to my mind, is writing which never fails to establish that seeming paradox, which often exhibits itself through the tumbling nuance of our own lives.

Recently, the newspapers I read reported the murder of two old women by a gang of thugs - two men, one 68 and the other 34 , and two young women, their girlfriends, less than half their ages: one twenty and the other 16 . With graphic intensity, these horrible murders demonstrate the darkness of the human heart. The victims, both in their $80 \mathrm{~s}$, were abducted, bludgeoned, and left to die simply because one of them criticized the gang's lifestyle.

The leader of the murderous pack, when interrogated after his arrest, swore viciously that both of the victims died at his hands alone, even though investigators later determined all of them participated. He tried to take the blame himself and keep the others from suffering punishments. Certainly, there is nothing saintly about anything connected with this horrifying tale, but even in its obdurate evil, there is some remnant vestige of selflessness in the murderer's choice to relieve the others of the burden of their punishments; he was, in his own perverse way, showing a kind of virtue. Writers who can capture both our sin and our saintliness capture, I think, the essentials of human nature, create memorable characters thereby, and write what I think of as truly moral fiction.

\section{Conclusion}

Finally, let me venture with some trepidation into areas far more yours than mine. I have been reading some South African literature for the past few weeks in an effort to understand something of South African life, since I believe literature's felt life offers us the best means by which experience a world other than one's own. And I have found in both Nadine Gordimer and J.M. Coetzee what I consider to be good examples of what Gardner would call "moral literature". 
John Gardner and the morality of choice

I don't know South Africa's critical estimation of Gordimer's recent None to Accompany $\mathrm{Me}$, but the novel strikes me as the harrowing tale of Vera Stark, a woman who makes a significant choice early in life - to take a lover while her husband is away in the military - and suffers the ramifications of that choice for the remainder of her life, even though her days offer some joy and even blessing. What the novel clearly suggests, it seems to me, is that actions have consequences, significant consequences she lacked vision to foresee. The novel is certainly no Sunday School lesson - its backdrop of the changing nature of society in South Africa is instructive (or at least was for me) and multi-faceted: the increasing alienation between Sibongile and Didymus Maqoma, resistance fighters in exile whose roles have changed radically as the new society is emerging, is real and poignant, Gordimer emphasizing the otherwise unseen human ramifications of the political struggle. Their daughter's sad lack of identity, a result, in part, of her European acculturation while her parents were in exile, may well be the most terrifying aspect of the novel, although Vera Stark's grandson offers no greater sense of hope. These characters are simply not the one-dimensional stick men which have come to characterize American media coverage of South African political struggles. If all politics is personal, as some would have us believe, then the greatest political battles both Vera Stark and the Maqomas face are struggles fought on the terrain of their own hearts. Gordimer's characters are, at least by my estimation, fully human, their lives characterized by choices they made or make humanly. This is, I believe, moral fiction - not because good triumphs over evil, but because the characters Gordimer has cast are true to what we know to be true even about ourselves.

Writing which is moral, to my mind, is true to what Gardner would call the kind of choice-making inherent in the human character. That kind of fiction, it seems to me, glorifies the Creator who fashioned us from the breath of his own nostrils; by necessity such writing identifies clearly the nature of our fallenness, as well as the triumphs we reach as image-bearers of the Creator of the Universe.

There lies my own fictional creed.

\section{Works cited}

GARDNER, John. 1984. The art of fiction. New York: Alfred A. Knopf.

GARDNER, John. 1983. On becoming a novelist. New York : Harper and Row.

GARDNER, John. 1978. On moral fiction. New York : Basic Books, Inc.

MENDEZ-EGLE, Beatrice, ed. 1983. John Gardner: True art, moral art. Living Author Series, No. 5. Edinburg, Texas : Pan American University School of Humanities. 